\title{
Water Potential in Petanu River Estuary and Model of Water Resources Management for Sustainable Agriculture in Gianyar Regency Bali Province
}

\author{
Eryani I.GST AG PT ${ }^{\#}$, Indayati Lanya ${ }^{*}$, Santosa I GST NGR ${ }^{\#}$, I Nyoman Norken ${ }^{\#}$ \\ \# Postgraduate Agricultural Science Program, Udayana University, Denpasar-Bali, 80225, Indonesia \\ E-mail: eryaniagung@gmail.com
}

* Udayana University, Sudirman street, Denpasar-Bali, 80225, Indonesia

\begin{abstract}
Water needs in the province of Bali from year to year increase along with the rise of population and tourism activities. A study conducted by the Ministry of Environment (2009) stated that Bali is already experiencing water deficit during the dry seasons since 1995 as many as 1.5 billion $\mathrm{m} 3$ / year. To overcome this water deficit issue, it will require researching on the potential water resources in Bali. Along the Petanu River, there are 25 irrigation weirs on a 4475.5 ha of land. Research was carried out in in Saba village, Gianyar Regency, Bali, along The Petanu River up to its estuary. The data collected from the research included primary and secondary data, namely: water quality, water quantity (water volume) in Petanu River estuary, precipitation, climate, and environmental conditions of the Petanu river. The data collected from the research site and the secondary data, the water quality was tested on the reseacrh site and in the laboratory before it was analyzed. The model used to detect water presence (the water system) along the Petanu River up to its estuary was procesed using a software called RIBASIM (River Basin Simulation). The result showed that there is a potential water source (water volume) on the estuary of the Petanu River estuary during the dry season as much as 6.16 million $\mathbf{m} 3$ and during the rainy season as much as $\mathbf{4 3 . 7 9}$ million $\mathrm{m3}$. Water quality in terms of physics (smell, taste, temperature, color, turbidity and salinity), meet the quality standards of class IV (for irrigation). Based on the simulation results on the RIBASIM software, the water resources in the Petanu River estuary can potentially be managed as irrigation water for horticulture agriculture along the coast of Saba. The potential water sources can be contained by building dams / reservoirs that are placed $\pm 300 \mathrm{~m}$ from the shoreline of Saba village in Gianyar regency. The water management model for the water sources in Petanu River to support sustainable agriculture can be put to use through water and soil conservation by controlling land use and cropping patterns that involve the community using the subak system.
\end{abstract}

Keywords—water potential; estuaries; water management.

\section{INTRODUCTION}

Bali Province, from year to year, experienced the increasing demands of raw water along with increasing population, tourism, and agricultural activities. Research from the Ministry of the Environment [7] stated that Bali has experienced a water deficiency (water availability is not sufficient to fulfil the ideal water availability per person), during the dry season since 1995 as much as 1.5 billion $\mathrm{m} 3$ / year, therefore, it is necessary to identify potential water sources in Bali. Population growth and demands for a more viable livelihood have been encouraging people to continue to strive to meet all need.

However, there will be negative impacts, especially on the water environment of the river. Water quality in the estuaries of the rivers in the province of Bali is still within the tolerancy limits. Criteria used to measure water quality, whether the water can still be consumed or not, is always associated with water quality standards, different from the criteria used to measure water quantity, which is whether the water that is available can fulfil public demands or not based on the amount of water volume or water availability within a certain timeframe. Water quality on the estuaries generally indicates the quality or condition of the water that is associated with a particular activity or purpose along the river. Water estuaries are a body of water which act as the entrance for river water which will later enter the sea, lakes, dams, oceans, or other bigger rivers. In coastal areas, estuaries are highly affected by inland water conditions such as the flow of freshwater and sediment movements as well as sea water movements due to tides, waves, and the influx of salt water into the ground. 
Potential water that is available in the river area or the estuary can be utilized as an addition to irrigation water, so the water from the river is not wasted into the sea during the rainy seasons, but instead it can be used to support the potential water sources during the dry seasons. Surface water flowing in river estuaries in Bali is yet to be used fully to fulfil public demands for fresh water and irrigation so as a result, this surface water is wasted into the sea and for this reason a research on potential water sources in Bali is needed in order to overcome water deficiency issue.

Petanu River is a pharennial (water flows throughout the year) kind of river, passing through two regencies: Bangli and Gianyar. The river has a length of $46.962 \mathrm{~km}$, watershed area of $96.886 \mathrm{~km} 2$. There are 25 dams along the river with a 4475,5 ha of irrigated land area.

The purpose of this research is to (1) Evaluate potential of water in estuaries of the Petanu River in Gianyar Regency so that the potential of water to support the availability of irrigation water in the province of Bali; (2) Determine a model of water resource management for areas around the Petanu River estuaries in Gianyar Regency

\section{LITERATURE}

\section{A. Potential Water}

Water is a very important factor for human life. Every day, it is estimated that people need a minimum of 100 liters of water per person, such as for drinking, cooking, bathing, washing, etc. Water potential are the water resources that already exist today and those that meet the water needs for the future. There are 401 rivers in Bali and 66 of them hold potential water sources [10].

\section{B. Water Resources Management}

Water resources management emphasizes on: attempts to plan, implement, monitor, and evaluate the implementations of the conservation of water resources, efficient use of water resources and control the destructive force air. Water resources management is the basic framework to planning, implementing, monitoring, and evaluating water resources conservation activities, utilization of water resources, and controlling the destructive force of water. Water quality management is an effort to maintain and restore the quality of water entering and available in the water source. Provision of water resources is the determination and fulfillment of the volume of water per unit of time to meet the water needs and water power as well as fulfilling various purposes according to quality and quantity.

\section{River estuary}

Estuaries or Loloan (in Balinese) in Bali are either consecrated or used for ablutions. Water in estuaries is already managed as raw water for Nusa Dua area, Jimbaran and Kuta through the building of estuary dams in Nusa Dua with an area of 35 ha, and water volume of 0.42 million $\mathrm{m} 3$, to collect water from the Badung River. Estuaries are a natural waterway that flow into other rivers, lakes, sea, or the ocean. River water that flows in accordance with the properties of water: from a high place to a lower place. The water ends up in estuaries.

\section{Water quality in the river}

River, as an ecosystem, requires a management system that must be adapted to the function of the river. A river that has been designated as a flood control system or as a source of water for the surrounding community, the quality of it water should be maintained, such as by dividing the water quality into different grades, reducing waste loads into the river, according to the quality standard rules of Government Regulation No. 82 in 2007 [8].

Estuarine waters is an area that is under the influence of sea water and fresh water. Odum (1996) states that an estuary is part of coastal waters that contain a high organic matter that is influenced by the tides with a large enough amount of abundance and diversity. Dahuri [9] says that the circulation of water in the estuary is strongly influenced by freshwater streams flowing from rivers in the upper body and the tide from the sea. The amount of the second discharge mass flow of water will affect the pattern of water mass stratification by salinity. Circulation of water in estuaries depends on the tidal range, vertical mixing between fresh water and sea water, and bottom topography. The characteristic feature of the estuary is shallow and turbulent water motion high dissolved oxygen, even at the base of low oxygen water mass mixing in the estuary is not exhaustive of the surface to the bottom. Estuary is a pollutant cleaning system.

\section{METHODOLOGY}

The research was conducted at the estuary of the Petanu River which ended in Saba beach in Gianyar Regency, Bali. The research is intended to determine the potential of water at the mouth of the river in terms of water discharge (quantity of water) and water quality in estuaries Petanu will be examined in the field and in the laboratory, estuaries water sampling conducted during the dry season months of September 2013 and the rainy season in January 2014. Water potential in terms of quantity is measured with current meter, morphology of the river mouth (estuary mouth width) was measured with a roller meter and for water quality will examined in the field and in the laboratory, the number of sample 3 but has properties - properties similar to water conditions around the mouth of the river Petanu.

Sampling was carried out at 3 point, with the distance of each point is $100 \mathrm{~m}$. Sampling was carried out at the first point approximately at $14: 50$, in second point at around 15:00, and in third point around 15.10. Water testing of the parameters of physics, chemistry and biology following steps: before inserting the water samples, mouth of the bottle is heated first, then fill the bottle until full of sample, then the sample discarded 3/4 parts, the mouth of the bottle is heated again, and then covered with aluminium foil to avoid contact with the water. After sampling, the bottle is stored in a special box so that the quality of water taken unchanged from its original nature.

The research variable quantity of water in estuaries include: water velocity (V) sampling area (A) water discharge $(\mathrm{Q})$ rainfall intensity. Analysis is conducted rain intensity rating curve, the amount of water flow and water quality in the estuary at the mouth of the River Petanu in terms of physics, chemistry and microbiology were 
compared with the water quality standard Class IV. Model of water management in the region Petanu River upstream to estuary RIBASIM [11], been processed using the software by entering the hydrological data. Map of the water system will illustrate the potential of water and water management system and building appropriate to manage the water.

\section{RESULTS AND DISCUSSION}

The results of this research have the potential of water (discharge water) in Petanu River estuary during the dry season at 6:16 million $\mathrm{m} 3$ and during the rainy season at 43.79 million $\mathrm{m} 3$. Water quality in terms of physics (smell, taste, temperature, color, turbidity and salinity), meet the quality standards of class IV (for irrigation). Watershed area of $96.886 \mathrm{~km}^{2}$ Petanu river, the main river length of 46.962 $\mathrm{km}$.

The potential of water in the watershed Petanu amounted to $6.86 \mathrm{~m} 3 / \mathrm{s}$, whereas during the dry season (in September 2013), the potential of water in estuaries Petanu measurement result of $0.88 \mathrm{~m} 3 / \mathrm{s}$. and during the rainy season (in January 2014) of $1.41 \mathrm{~m} 3 / \mathrm{s}$. Based on picture 1 . It can be concluded that the actual research results approximately equal to the flow hydrograph results obtained from measurements of the automated tools in the Village Bedulu, Blahbatuh, $\pm 100 \mathrm{~m}$ downstream of Goa Gajah.

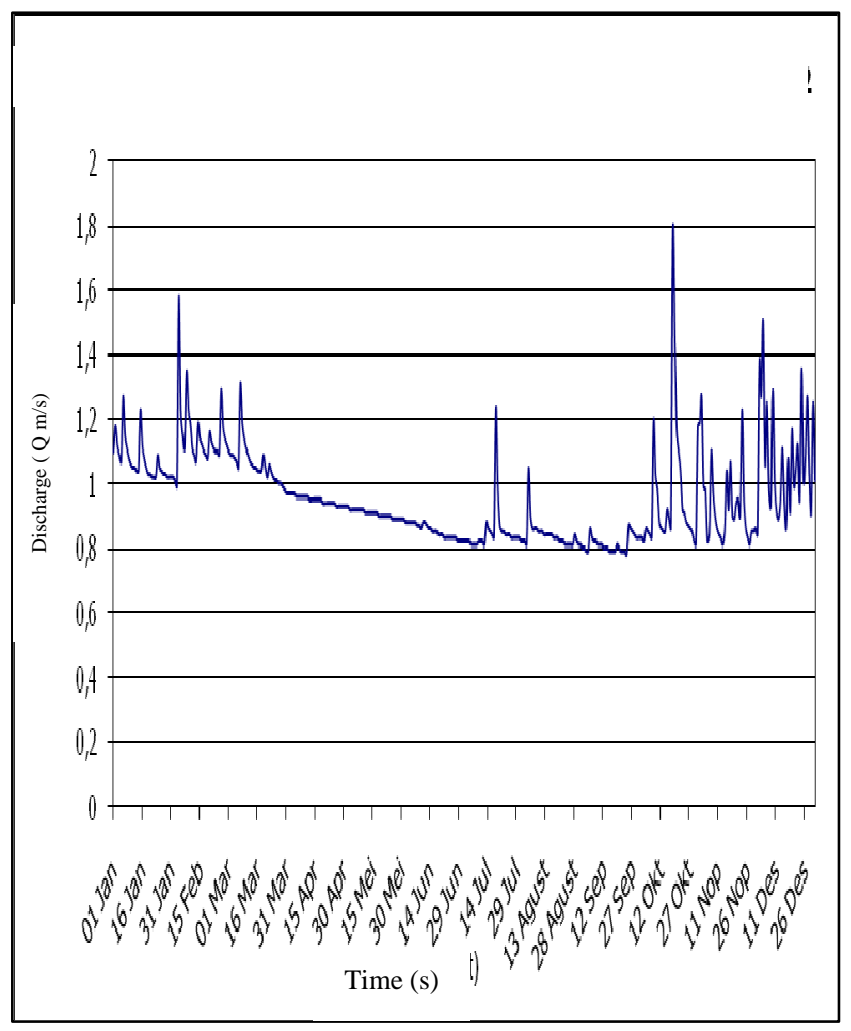

Fig. 1 Amount of discharge Petanu River
TABLE 1

THE FLOW VELOCITY IN THE ESTUARY OF RIVER PETANU (HORIZONTAL CROSS SECTION OF THE RIVER ESTUARY)

\begin{tabular}{|l|c|c|c|c|}
\hline \multicolumn{4}{|l|}{ Water flow speed } & \multicolumn{2}{l|}{ Specification } \\
\hline I & II & III & IV & Measurement point \\
\hline 1,2 & 1,5 & 1,8 & 2,1 & High water level H $(\mathrm{m})$ \\
\hline 0,505 & 0,532 & 0,484 & 0,517 & The flow rate V $(\mathrm{sec})$ \\
\hline 0,393 & 0,384 & 0,417 & 0,427 & The flow rate V $(\mathrm{sec})$ \\
\hline 0,465 & 0,402 & 0,465 & 0,488 & The flow rate V $(\mathrm{sec})$ \\
\hline & & 0,456 & & The average velocity $(\mathrm{m} / \mathrm{sec})$ \\
\hline
\end{tabular}

Source: measurement results

Based on the results obtained the flow velocity (V) average occurring in river estuary Petanu is $0.456 \mathrm{~m} / \mathrm{sec}$. The potential of water in River Basin until estuary Petanu based process using RIBASIM software input the data in the form of Hydrology (rainfall, evaporation), stream flow, water flow in river estuary of the results of measurements and maps Petanu watershed and the area irrigated. use of water to measure the amount of time half-month period, then the following scenario obtained through a process and the results of the water system in the river estuary upstream to Petanu according to the water system map (Picture 2) and specifically for water management in the river estuary given circled. Water resources management in river estuaries Petanu can be implemented by making dams / reservoirs are located $\pm 300 \mathrm{~m}$ from the shoreline Saba Gianyar regency.

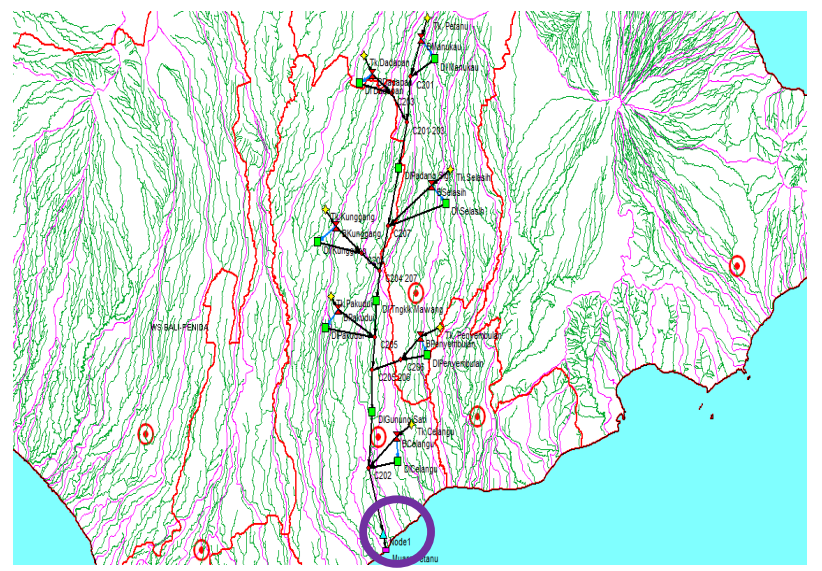

Fig. 2 The condition of the pattern of water in river estuary upstream to Petanu with RIBASIM

The final results of the simulation process is: The water balance in watersheds Petanu for irrigation water amounting $64.96 \%$, while the raw water at $100 \%$ Potential water resources contained in the watershed Petanu amounting 6.86 $\mathrm{m} 3$ / s (216.45 million $\mathrm{m} 3$ ), and the total availability of water is utilized for irrigation of $5.251 / \mathrm{sec}$ with an average allocation of $1.75 \mathrm{lt} / \mathrm{sec} / \mathrm{ha}$. Water for household needs (RK) of $0.13 \mathrm{~m} 3 / \mathrm{s}$ (117 366 inhabitants). The water requirement for the tourism industry amounting $0.0022 \mathrm{~m} / \mathrm{s}$ (724 rooms) and is wasted through the river estuary to the Sea amounting $5.17 \mathrm{~m} 3 / \mathrm{s}$ (163 million $\mathrm{m} 3)$. 
TABLE II

WATER QUALITY IN ESTUARIES PETANU THE WATER QUALITY STANDARD CLASS IV

\begin{tabular}{|c|c|c|c|}
\hline Parameters & $\begin{array}{c}\text { Dry Season } \\
\text { (September } \\
\text { 2013) }\end{array}$ & $\begin{array}{c}\text { Rainy } \\
\text { Season } \\
\text { (January } \\
\text { 2014) }\end{array}$ & $\begin{array}{c}\text { Quality } \\
\text { Standards } \\
\text { class IV ( The } \\
\text { Quality } \\
\text { Standard rules } \\
\text { of Government } \\
\text { Regulation No. } \\
\text { 8/2007) }\end{array}$ \\
\hline \multicolumn{4}{|l|}{ Physics } \\
\hline Odour & Odorless & Odorless & Odorless \\
\hline Taste & Brackish & Brackish & no taste \\
\hline Temperature & $28,4^{\circ} \mathrm{C}$ & $28,1^{\circ} \mathrm{C}$ & Normal \\
\hline Color & $2,5 \mathrm{PtCo}$ & $2,5 \mathrm{PtCo}$ & $50 \mathrm{PtCo}$ \\
\hline Turbidity & $12,6 \mathrm{NTU}$ & $46,1 \mathrm{NTU}$ & $25 \mathrm{NTU}$ \\
\hline Salinity & $1,4 \%$ & $1,2 \%$ & - \\
\hline \multicolumn{4}{|l|}{ Chemistry } \\
\hline $\mathrm{Ph}$ & 6,96 & 6,34 & $5-9$ \\
\hline BOD & $3,42 \mathrm{Mg} / \mathrm{ltr}$ & $2,96 \mathrm{Mg} / \mathrm{ltr}$ & $12 \mathrm{Mg} / \mathrm{ltr}$ \\
\hline COD & $12 \mathrm{Mg} / \mathrm{ltr}$ & $9,0 \mathrm{Mg} / \mathrm{ltr}$ & $100 \mathrm{Mg} / \mathrm{ltr}$ \\
\hline Detergent & $0,038 \mathrm{Mg} / \mathrm{ltr}$ & $0,047 \mathrm{Mg} / \mathrm{ltr}$ & $0,5 \mathrm{Mg} / \mathrm{ltr}$ \\
\hline \multicolumn{4}{|l|}{ Microbiological } \\
\hline Total coliform & $1600 \mathrm{jml} / 100 \mathrm{~m}$ & $\begin{array}{c}2100 \\
\mathrm{jml} / 100 \mathrm{ml}\end{array}$ & $\begin{array}{c}10.000 \\
\mathrm{jml} / 100 \mathrm{ml}\end{array}$ \\
\hline
\end{tabular}

Source: measurement results

Water potential in terms of quantity (water discharge) Petanu estuary during the rainy season can be accommodated by making reservoirs / dams are planned within $\pm 300 \mathrm{~m}$ from the beach in Gianyar regency Saba. Water quality in estuaries Petanu tested the water quality standard is a standard class IV Irrigation water

Management of water resources in the basin Petanu from upstream to estuary located in Saba beach, can be done by: Conservation of water resources for agricultural sustainability is a way: the preservation of water resources in a way to accommodate the water source in the season when the river estuary rain and utilized during the dry season. Water quality management can be done consistently perform water quality testing according quality standards, water pollution control with step socialize the. Exploitation of water resources is able to perform: stewardship of water resources, provision of water resources, and use of water resources. Control the destructive force of water that is directed at activities: prevention, mitigation, and recovery as well as flood management with eco-drainage step of conducting a business or dispose of excess water to drain into the sea through the river or river estuary with time as optimally as possible, so it does not cause problems flooding in river and surrounding areas, due to higher peak flows and shortening the time to reach peak flows.

Aspects of conservation, natural resource utilization, and control of river water damaged power Petanu is improving step by step Petanu River region conditions associated with natural resource management is carrying out treatment can be done for short-term protection of water resources and riparian areas with normalization arrangements river estuary. For the medium term, namely the manufacture of reservoirs / dams and drainage systems with drip irrigation. For longterm measures to reduce the deposition of sediment at the mouth of the estuary of river so as not until flood the capital with dredging and maintenance dredging and jetty construction of short / long-adapted to the environment Petanu River estuary.

\section{CONCLUSIONS}

Based on the analysis can be summarized as follows: Water flow rate (V) obtained an average of the results of research on river estuary Petanu is $0.456 \mathrm{~m} / \mathrm{s}$ approximately equal to the flow velocity of the results of measurements at the weir.

Watershed area amounting $96.886 \mathrm{~km}^{2}$ Petanu river, the main river length of $46.962 \mathrm{~km}$. The results of this research have the potential of water (discharge water) in Petanu River estuary during the dry season amounting 6:16 million $\mathrm{m} 3$ and during the rainy season amounting 43.79 million $\mathrm{m} 3$. Water quality in terms of physics (smell, taste, temperature, color, turbidity and salinity), meet the quality standards of class IV (for irrigation). Discharge Petanu water in estuaries, the potential to be managed as surface water resources by making a reservoir to store water in he rainy season in order to be used during the dry season for irrigation water

Measurement of water quality in terms of physics (smell, taste, temperature, color, turbidity and salinity), meet the water quality standard Class IV (irrigation water), while in terms of Chemistry: BOD (Biochemical Oxygen Demand), COD (Chemical Oxygen demand), and in terms of microbiological (total coliforms) does not meet the water quality standard class IV (irrigation water). Model of water resource management in river Petanu, especially in the river estuary can be implemented with aspects of conservation, efficient use of natural resources, and control the destructive force of water. Referral resource management will be able to generate sustainable natural resource management planning to support sustainable agriculture Management of water resources in river estuaries Petanu can be carried out with water and soil conservation by arrangements land use and cropping patterns that involve the community with the subak system.

\section{NOMENCLATURE}

$\begin{array}{lll}\text { A } & \text { Watershed area } & \mathrm{km}^{2} \\ \text { BOD } & \text { Biochemical Oxygen Demand } & \mathrm{Mg} / \mathrm{ltr} \\ \text { COD } & \text { Chemical Oxygen demand } & \mathrm{Mg} / \mathrm{ltr} \\ \mathrm{H} & \text { High water level } & \mathrm{m} \\ \mathrm{L} & \text { the main river length } & \mathrm{km} . \\ \text { RK } & \text { Water for household needs } & \mathrm{m} / \mathrm{sec} \\ \text { V } & \text { water flow rate } & \mathrm{m} / \mathrm{sec} \\ \text { Q } & \text { water discharge } & \mathrm{m} 3 / \mathrm{s}\end{array}$

\section{ACKNOWLEDGMENT}

We would like to thank the committee in 2014 0n the SAFE receipt of the manuscript. Delivered on this occasion to thank the Udayana University for allowing the author to be able to continue the Study of Ph.D. To all those who who have helped and guided in the preparation of this research we thank you. 


\section{REFERENCES}

[1] Mock, FJ,. Land and water availability capability appraisal appraisal, Indonesia UDDP / FAO, Bogor. 1973.

[2] Grigg, NS, Water Resources Management: Principles, Regulations, and Cases. New York: McGraw-Hill. 1996.

[3] Moises Gonzalez, Jose A. Rivera, J. Jarret Garcia, and Sam Markwell,. Qualitative Modeling and Visualization Methologies for Social-Ecological Dimensions of Regional Water Planning on the Rio Chama, the Universities Council on Water Resources. Journal of Water Research \& Education Conteporary Issue 152, Pages 55-68, December 2013.

[4] Yulistiyanto.B., Kirinoto, AB,. Analysis of Water Resource Utilization in WS Paguyaman with RIBASIM, the journal Media Engineering, No.2 May 2008 XXX Edition, UGM. 'Yogyakarta. Accessed on May 3, 2013.

[5] Anschuetz, K.F. Not Waiting for the Rain Integreted System of Water Management byPre-Colombian Pueblo Farmers in NorthCentral New Mexico. Dissertation, Department of Anthropology, University of Michigan Ann Arbor.UMI Dissertation Service. 1998.
[6] Ministry of Public Works, Directorate General of Water Resources, Central River Basin-Penida Bali, Report of Water Resources Management Plan Phase I, PT Indra Karya Region I, Surabaya. 2012.

[7] Ministry of Environment. Decree of the Minister of the Environment No. 115 of 2003 on the Establishment of Water Quality Status. Ministry of Environment. 2003.

[8] The Quality Standard rules of Government Regulation No. 82 in 2007.

[9] Dahuri, R., A. Damar. 1994. Methods and Techniques of Water Quality Analysis. Environmental Research Center (PPLH). IPBBogor Research Institute.

[10] Department of Public Works. 2011. Management of River Basin Water Resources Penida Bali. Bali Province.Yulistiyanto.B., Kirinoto, $\mathrm{AB}$, 2008, Analysis of Water Resources Utilization in WS Paguyaman with RIBASIM, journals Media Techniques, 2 Year XXX Edition May 2008, UGM. Yogyakarta. Retrieved May 3, 2013

[11] Yulistiyanto.B., Kirinoto, AB, 2008, Analysis of Water Resources Utilization in WS Paguyaman with RIBASIM, journals Media Techniques, 2 Year XXX Edition May 2008, UGM. Yogyakarta. Retrieved May 3, 2013. 